\title{
On Otherness: An Analysis in the Context of Ibn Sīnā's Theory of Relation*
}

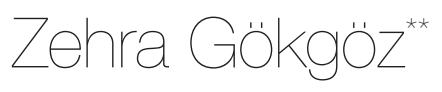

\section{Translated by Sacide Gökgöz}

\begin{abstract}
The mode of existence of relatives has been a matter of debate throughout the history of thought. Having evaluated the debate through the contrast between a first intelligible that has individuals in the external world and a second intelligible that has no counterpart at the individual level in the external world, Ibn Sinna believed the relative to be a categorical accident with individuals that can be pointed at in the external world. In the Metaphysics of al-Shifä, Ibn Sinnā proposed a solution aimed at eliminating the objections based on the infinite regress against his view. The article tests the applicability of the model built in this solution to the meaning of otherness (al-mughäyara), the results of which reveal the incompatibility of otherness with this model as a problem. When examining the source of this problem, the following findings are noted: The categorical relative ( $a l-m u d \bar{d} f$ ) and pure relation (idafa) are not the same thing. Pure relation is a general concept upon which the categorical relative is based and to which it cannot be reduced, because the predicate of oneness (wahda) becomes valid for multiplicity (kathra) through pure relation. Otherness is a general predicate that is inherent in and coextensive with pure relation; in this way, otherness is included in the most general class of concepts that explain the order in the existence of all existents including the categorical relative. As Ibn Sīnā's solution model in Metaphysics aims to explain the result of pure relation in essences, it cannot be applied to pure relation phases that prioritize results and transcend categories and thus cannot be applied to otherness.
\end{abstract}

Keywords: Pure relation, relative, otherness, Ibn Sīnā

\footnotetext{
* This article was written based on my MA thesis titled “İbn Sînâ'da İzafet Kategorisi” (The Category of Relation in Ibn Sinā) presented to Marmara University Institute of Social Sciences. I would like to thank Prof. Hikmet Yaman and the anonymous referees of the journal for their suggestions on the article.

** Ph.D. Candidate, Marmara University, Department of Islamic Philosophy.
} 


\section{Introduction}

W

hen examining the parts constituting the proposition "That red apple is similar to that red rose to its right" in terms of having counterparts in the external world, certain schools of thought that accept the apple and redness to have individuals that can be pointed at in the external world consider the existence or the mode of existence of "being to the right" and "similar" in the external world to be disputable. While they find common ground in accepting Aristotle's substance-accident scheme that includes relatives as an independent category, the approaches of these schools of thought constitute a spectrum ${ }^{1}$ consisting of a general and undetailed acceptance, a strong rejection, and conditioned acceptances between the two ends. The most fitting person to be positioned at the general acceptance end of the spectrum is Aristotle himself, the author of Categories. Aristotle did not discuss the mode of existence of relatives. However, because categories are the classification of the objects that make up the external world under high genera, the idea is that some objects existing in the external world are also classified under the category of relation. ${ }^{2}$ At the other end of the spectrum are the mutakallimūn (Muslim theologians), who deny the existence of relatives in the external world. For them, relatives, just like blindness, are meanings that are verified for existing objects but are themselves in the mind and not in the external world. ${ }^{3}$ Positions are found between these two ends that have

1 The limitation of the spectrum to those who accept the substance-accident scheme excludes the Stoics, an important influence in the history of this discussion. The Stoics not including relation in the structure of reality and the Neo-Platonists holding the relevant discussion against this view are mentioned as common knowledge in modern studies conducted on this subject. Julius R. Weinberg, Abstraction, Relation and Induction Three Essays in the History of Thought (Madison \& Milwaukee: The University of Wisconsin Press, 1965), 82. Despite this, the Stoics are deliberately excluded from this ranking because the Stoic ontology suggests a structure of reality different from the Aristotelian ontology in which existents are classified under separate categories from each other. In their structure, above all, the existent and the body are coextensive. "Relative state" is a synthetic category that expresses the connection of bodies both between each other and between "non-corporeal reality elements" that are not existent themselves but that provide the conditions of existence and comingto-be for bodies. See Melike Molac1, "Güncel Bir İmkan Olarak Stoa Ontolojisi" (PhD Diss., Hacettepe Üniversitesi, Sosyal Bilimler Enstitüsü, 2018), 80-81. Thus, the discussion focused on relation that Plotinus and Simplicius held against the Stoics appears to be a discussion aiming to force them to admit the structure of reality rather than the realness of relation. In fact, Plotinus said in the context of the relevant discussion that Stoics, who see existents as only bodies, must either accept the existence of intellectual objects (hence relations), or that, if the existent and the body are coextensive as they claim, objects such as intellect and soul which are among qualities with which the bodies are distinguished and therefore qualities, are nothing but names. Orna Harari, "Simplicius on the Reality of Relations and Relational Change,” Oxford Studies in Ancient Philosophy 37 (2009): 250.

2 Weinberg, Abstraction, Relation and Induction, 68.

3 For statements about the majority of mutakallimūn not accepting the existence of relations in the 
developed theories with the aim of explaining the mode of existence of relatives in the external world, and these have diversified and increased, especially in the postIbn Sīnā world of Latin philosophy. ${ }^{4}$

Henninger's interpretation is important for narrowing down this spectrum to the Ibn Sinā focus: Henninger considers the relation ${ }^{5}$ discussions in the history of philosophy to be discussions not of its proof but of its quality ${ }^{6}$ because causality is a meaning that is thought to be in objects outside the mind, and this realness can be provided by the realness of relations. ${ }^{7}$

What involves mutakallimūn at this end of the spectrum is not only that they discussed the existence of relatives in line with the Aristotelian substance-matter scheme, but more importantly that the infinite regress argument they used to prove their views had also become the minimum success threshold to cross for the realists. Although schools and theories vary, the persisting problem remains the same: A view that accepts the existence of relatives in the external world must, above all, have eliminated the infinite regress problem.

As a relation that two things have with respect to each other, otherness (almughāyara $)^{8}$ has almost never been examined ${ }^{9}$ in the context of the relation

external world and examples of privational meaning, see al-Sayyid al-Sharıf al-Jurjānī, Sharh alMawāqif: Mevâkıf Şerhi, trans. Ömer Türker, II (İstanbul: Türkiye Yazma Eserler Kurumu Başkanlığ1 Yayınları, 2015), 575, 577; al-Taftāzānī, Sharḥ al-Maqāṣid, ed. 'Abd al-Raḥmān 'Umayra, II (Beirut: 'Âlam al-Kutub, 1998), 465, 467. For the passages that constitute a source in terms of content and form for the opinions and proof conveyed in these works, see Fakhr al-Dīn al-Rāzì, Sharh 'Uyūn alhikma, ed. Aḥmad Ḥijāzī al-Saqqā (Tehran: Mu’assasat al-Ṣādiq, 1415), 103-4; Fakhr al-Dīn al-Rāzī, alMabāhith al-mashriqiyya, ed. Muhammad Mu tașim Billāh al-Baghdādī (Beirut: Dār al-kitāb al- 'Arabī, 1990), 560-63.

4 For various comments such as that, although the concept of relative has a counterpart in the world, the relatives in the mind and the external world are not isomorphic, or the relative is a "special kind" that is in the objects as a disposition and becomes actualized through the perception of the mind, see Jeffrey Brower, "Medieval Theories of Relations", Stanford Encyclopedia of Philosophy, https://plato.stanford. edu/entries/relations-medieval/ (Accessed September 1, 2020)

5 The basic concepts regarding the subject will be explained in the following pages. To briefly note, "relation" is a polysemous concept in Ibn Sīnā's use referring both to the name form of the existents in the scope of the category as well as to a general state valid for all existents. Throughout the article, "relation" will be used flexibly in accordance with its polysemy, and in order to achieve the conceptual clarity required by the problem, the distinction between the concepts of (i) pure relation (idāfa) and (ii) the relative (al-mudāf) will be utilized.

6 Mark Gerald Henninger, Relations: Medieval Theories 1250-1325 (Oxford: Clarendon Press, 1989$), 4$.

7 Richard Sorabji, The Philosophy of the Commentators 200-600, Volume 3: Logic and Metaphysics (London: Bristol Classical Press, 2012), 88.

8 "Otherness" will be used to mean essential otherness in the article unless otherwise stated (e.g., "individual other", "numerical otherness").

9 When looking at the history of philosophy in general, the meaning of "otherness" (al-mughāyara) 
discussions that started with Neo-Platonist commentators and flourished in the Western Latin philosophy. Instead, the discussions were focused on relations specified through an essence (māhiyya). For example, similarity is somehow associated ('alāqa) with an essence in the category of quality, equality is associated with quantity, and being to the right is associated with the body substance; these are the relatives whose mode of existence has been investigated. As for otherness, it is a meaning that is not specified with respect to the categories, and every existent that has its own identity regardless of its category is qualified in itself against those other than itself through otherness. However, otherness can only be thought of as a relative concept. That being the case, every view that aims to explain the position of relatives in reality is expected to pay attention to the concept of otherness or present a theoretical basis from which an explanation regarding otherness can be acquired indirectly.

Ibn Sīnā's most detailed analysis concerning relatives' mode of existence is found in Metaphysics (III.10), where he proposes a solution to the ontological problem. He also does not directly mention the meaning of otherness in his examination in this chapter. ${ }^{10}$ The first step in investigating the position and function of otherness as a relation in reality is testing whether the solution in Metaphysics can also be read as an indirect explanation of otherness. To do this, summarizing the ontological problem from Ibn Sinnā's point of view and the solution he proposed to this problem are first needed.

Ibn Sīnā described the discussion about relatives' mode of existence in the framework of two possibilities: "Being with respect to another thing/pure relation (id̄āfa)" either (a) exists in the external world ( $a^{\prime} y \bar{a} n$ ) or (b) has no counterpart in the external world and is one of the second intelligible (al-ma 'qūlāt al-thāniya) concepts that explain the states of an object (e.g., being universal, particular, genera, differentia) which attach to the object after it is perceived, and its concept occurs in the mind." ${ }^{11}$ The proof of those who adopt the first view is that the objects

is stated to have had an important place in Platonic thought. While Weinberg also pointed out the diversity of comments, he described and adopted the view that otherness to Plato was not "a form between two forms" but to have acted as a principle that operates by pervading all forms and providing their differentiation from each other. Weinberg, Abstraction, Relation and Induction, 67. In that case, not only is otherness not an ordinary form, it is also not just a relation; it is the principle of the relation that accompanies all forms because relation requires real or considerational divergence.

No study is found at the level of a thesis or article that has examined the concept of otherness in the philosophy of Ibn Sīnā.

11 Ibn Sīnā, Metafizik [Metaphysics], trans. E. Demirli \& Ö. Türker, I (İstanbul: Litera Yayıncılık, 2013), 
in the external world are the subject of relations independent of the scrutinizing of a perceiving subject. Whether thought of or not, the red apple is to the right of the red rose and is similar to it, and Ali is Veli's father. Proponents of the second view, in contrast, draw a picture describing the position of relation if an individual existence (i.e., the existence of redness and rose) is attributed to being to the right and similarity, and point out that this picture is not suitable for the external world because of the infinite regress problem. The picture leading to the infinite regress is this: If similarity as a unit of accident is separate from the red objects A and B, it has to exist in $A$ and $B$, and at the same time stand as a link running between the two, because the association of something unique to $A$ with something unique to $B$ cannot be established without a link between them. In that case, an infinite regress occurs whether the accident of similarity is considered separately in A and B or as the link running between them.

The vertical infinite regress ${ }^{12}$ that occurs separately in A and B is due to the fact that, in order for similarity to occur and be in red, red has to be simultaneously apprehended with the meaning of "with respect to another thing." This simultaneity is also a relation, and because a relation is accepted as an independent accident, it too requires another simultaneity in order to attach, and this goes on to infinity. Under these conditions, the similarity one predicates of red can actually never be acquired as something separate from red.

The claim of vertical infinite regress appears to be based on no type of relative existing unless the meaning of "with respect to" attaches to an essence. When not attached to an essence, relation is a contentless, simple link with no meaning other than the function of linking one thing to another thing. For the simple link to occur as the relation of similarity in an object within the category of quality, it needs to attach to the accident of quality and take its content from it. Thus, "with respect to" takes on the character of whatever it attaches to: If it attaches to quantity, equality occurs. If it attaches to the human substance, relations such as teachership occur due to its properties linked to being a rational soul (nātiqu). The necessity above all else for the simple link to attach to essences for these relations to occur leads to an infinite regress because the attachment is also a contentless link. If

141.

12 I use the terms "vertical" and "horizontal" to distinguish between the infinite regression that prevents the relative accident from occurring in a subject and the infinite regression that is formed by the idea of a link between two subjects. 
a contentless meaning is accepted to be in the external world as an individual, a contentless individual like it will exist, functioning only as a link between it and the essence from which it gets its content. Therefore, there will be infinite individuals.

The horizontal infinite regress between A and B occurs because every relative requires a correlative. A similar thing cannot be apprehended without what is similar to it, just as a father cannot be apprehended without his son. If the relative accident in $\mathrm{A}$ belongs only to $\mathrm{A}$, if the relative accident in $\mathrm{B}$ belongs only to $\mathrm{B}$, and neither of them exists between the two as a link, the association of the relative with its correlative cannot be explained. In this case, the relative accident needs to be between A and B in order to qualify them. An assumed link between two things requires two more links like itself in order to be in the extremes (țaraf), and the repetition of this requirement generates an infinite regress. ${ }^{13}$ In addition, assuming a horizontal link would require a numerically one accident to be in two subjects; however, this is not the case in Ibn Sīnā's view. ${ }^{14}$

The two-pronged infinite regress described so far is the argument of those who object to the existence of the relative in the external world. Ibn Sinnā argued for the existence of the relative in the external world by proposing a two-sided solution to the problem of infinite regress. Briefly pointing out the distinctions in the group of concepts about relation would be appropriate before proceeding to the summary of the solution. These concepts can be ranged from simple to compound as follows:

Relationship (nisba) is the most general meaning in the conceptual group of pure relation. It is the prerequisite for talking about extremes both in the context of pure relation and in general. It can be noticed if and only if the extremes are apprehended. Pure relation (id̄a fa) is a meaning that has no content other than "with respect to", and that is reified (ta 'ayyun) only by providing the "with respect to" meaning of one thing toward another. The reification of pure relation through something brings about the relative (al-muḍāf), i.e., a relativized meaning. Although Ibn Sīnā wrote

13 "If relations were to exist in things, then from this it would necessarily follow that relations become infinite. For there would then exist between father and son a relation. This relation would exist either [in common] for both, for only one of them, or for each [separately]. [Now,] inasmuch as fatherhood belongs to the father, occurring accidentally to him, (the father being subject to its occurrence), it would be related, the case being similar with sonship. Thus, there would be here (a) a connection between fatherhood and the father and between sonship and the son outside (b) the connection between father and son. It would then follow necessarily that for [each] relation there is another relation, and that this would proceed infinitely (...)" Ibn Sīnā, The Metaphysics of The Healing, trans. M. E. Marmura, (Provo, UT: Brigham Young University Press, 2005), 120.

14 Ibn Sīnā, Metafizik [Metaphysics], I, 140; Ibn Sīnā, al-Ta 'īqaāt, ed. 'Abd al-Raḥmān Badawī (Beirut: alDār al-Islāmiyyah, 1973), 143. 
that the correct name of the category is the category of pure relation, understanding this as a category that occurs for other categories due to the meaning of pure relation appears reasonable because, when the terminology he used is carefully observed, the existents classified under the category of pure relation are not pure relations but relatives (muḍāāt). For instance, similarity is the state of a quality that has been the subject of pure relation and relativized; it is the real relative. The type of relative excluded by the adjective "real" is the common relative. To be a common relative is an adjective that applies to everything in the external world, be it substance or accident. This is because being in the external world requires being in a state of "that which attaches and that which is attached" with other essences. Even if there is no other consideration, just the fact that this attachment requires mutual meanings between the extremes makes every existent relative in general. ${ }^{15}$ The debate is not about whether such a common relative, be it relative in itself or not (which is qualified by relative meanings due to its presence in the external world), exists or not; the debate is about whether the meaning itself (i.e., the real relative) that causes objects to be qualified as relatives exists in the external world or not.

When reviewing the views of both sides with this conceptual precision, the argument of the realists will be noticed to appear inadequate or at least unclear compared to that of the conceptualists. As Ibn Sinnā presented, the realists are content with asserting that propositions such as "Ali is Veli's father," which we can affirm with common sense certainty, need to have something that provides truth in the external world. However, the truth of a proposition does not require all of its elements to be individuals suitable to being pointed at sensorially or intellectually in the external world. While the proposition of "the body is a genus" is true, existence as an individual is valid only for the body; meanwhile, being a genus is valid for the universal concept of the individual in the mind. In the view of conceptualists, which Ibn Sinnā presented in detail, their argument was based on the nature of pure relation compared to the realists' common-sense based and relatively unclear statements. Conceptualists believe that, when analyzing the meaning of similarity, nothing else is seen to remain besides the essence of red and pure relation. What makes red similar is that it is the subject of pure relation. Because pure relation does not meet the conditions of existing as an accidental individual, only red itself remains in the external world.

15 Ibn Sīnā, Kategoriler [Categories], trans. M. Macit (İstanbul: Litera Yayıncılık, 2010), 154-55; Ibn Sīnā, al-Ta 'īqāt, 144. Similarity, redness and object in the "similar red objects" phrase are all common relatives in terms of being the subject of a relation of "that which attaches and that which is attached." Real relatives are only similarity and attachment. 
That being the case, the following question can be asked: Being a reified relation (according to Ibn Sinnā, a relative), what is similarity according to the conceptualists? Does it have any counterpart in the external world or is it a "special kind" with external foundations and itself only in the mind with its individuals?

The passage in question from Metaphysics only presents the conceptualists' counter-arguments, not their theories. In the argument, conceptualists discuss not what relation is but only what it cannot be. Ibn Sinnā considered the ontological position envisaged about relation in such a reasoning to be a state akin to a second intelligible. According to this, Ibn Sīnā's answer to our question that various models before and after him have tried to answer is, in general terms, a second intelligible. Therefore, Ibn Sinna evaluated the views of the sides through the contrast between the possibilities of being (a) a kind of second intelligible (e.g., being universal, genus, subject-predicate, which attach to the intelligibles of the objects after they are received in the mind) and (b) a first intelligible that is classified under an independent category, has individuals in the external world, and occurs in the mind with the first degree of intellection. ${ }^{16}$ It is worth noting that the possibilities on both sides of the contrast do not go beyond a realist attitude in the broad sense, because even if second intelligibles do not have individual counterparts in the external world, they do explain the conditions of the individuals' occurrence in the external world. Body is the meaning that the individuals of pen, cloud, horse, and human have in common. Genus is the concept itself that expresses this commonality and does not exist in the external world in the sense that it has no individual that can be pointed at. This can be said for not only the five universals but also for the forms of proposition and comparison, which are compound second intelligibles. The forms themselves do not exist in the external world, but the truth of the results acquired through these forms can only be possible for the object in the external world if the forms reflect the states of the object. In this case, Ibn Sinā's evaluation of the debate by contrasting a first and second intelligible provides the opportunity to make this restriction: Ibn Sinnā evaluated the problem he had inherited of the ontology of relatives not in the framework of a realism opposed to true conceptualism, but in the framework of a realism that contains two possibilities. In one of the possibilities, the relative is an accident that can be pointed at. In the other possibility, it is a property of the structure that operates in every individual and ensures the existence of substance, quantity, and quality as individuals that can be pointed at. 


\section{Ibn Sīnā's Relative Model}

Ibn Sīnā considered relatives to exist in the external world, and in Metaphysics, he proposed a solution in favor of realism with the aim of overcoming the objection based on the infinite regress. The solution explains that the relative is an intellectual, independent, categorical type against vertical infinite regression and that the relative is not a meaning subsistent between two things against horizontal infinite regression. The solution is built upon the following basic propositions: (i) There is a foundation of relation in objects. (ii) Pure relation, whose independent existence in the external world the conceptualists do not accept, is not in the external world in its pure form but rather exists as a reified relative. (iii) The definition of the relative and its isomorphic intelligible should be considered separately from the essence of the relative itself, and its intelligible that occurs in the mind should be considered separately from the process of the intelligible's occurrence. (iv) The relative is not a numerically one accident that is present in or between two things.

It would be fitting to try understanding the solution that emerges through the consistent expansion of these propositions in light of the key statements about the essence of the relative in Categories. Ibn Sinna included the following remarks in Categories in the context of explaining how relations become species:

The relative does not have a singular existence. Its existence is as a thing that attaches to objects, and its specification is through the specification of this attachment. The specification through attachment is understood in two ways: The first is that the attached and the relation are taken together (i.e., taken from separate categories, not just from the category of relation but a compound of two categories). The second is that the relation is taken together with such a specific intellectual attachment and the two of them are taken together as a single thing that is accidental to the attached. This is how relation occurs and becomes a species. ${ }^{17}$

The passage mentions that the special existence of the relative (i.e., its essence) is an intellectual compound but that it is taken as simple. Accordingly, two categories are indicated when stating "similar red": Quality and relation. The categorical relative is similarity. As can be remembered, conceptualists argue that only the quality remains when we take pure relation from what we call similarity. Meanwhile, Ibn Sīnā considered "quality with respect to something" to bring about a type that is classified under a non-quality category. Just as relation becomes a

17 Ibn Sinā, Kategoriler [Categories], 155. The existence of the relative "not being separate, and being attached to other things" should be understood at the level of essence and not existence because attachment at the level of existence is not unique to the relative. It is valid for other accidents as well. 
species in this way, an essence's reception of a relative accident compatible with its own mode of existence is also explained by the foundation that accompanies the essence in the external world (the first proposition). The foundation is one of the essential (dhātī) accidents through which the substance is realized (tahaqquq), and is included in either the category of quantity or quality. If so, then the accidental meaning in the substance also functions as a foundation for the attachment of relation. Just as meaning is in a numerically one subject when taken as an accident, it is also in one subject when it functions as a foundation. Pure relation becomes suitable to exist in the external world through the occurrence of the foundational meaning as an individual of a new, independent essence. Therefore, pure relation in the form that has not become a species cannot exist in the external world (the second proposition).

The reason for objecting to the relative's realization in the external world based on the thought that it will face the vertical infinite regress barrier is that the essence of a relative specified through an intellectual compound and the realization of this essence as any other simple accident are confused with each other. There is indeed a complexity in the occurrence of the relative essence, and when the human mind examines the intelligible of the essence, it comes to realize that the representation of this occurrence also directed its own intellection. Attributing existence in the external world to the unreified pure relation captured in this realization makes one think that an environment of infinite regress has occurred. Ibn Sīnā distinguished among the relative in the external world, the relative in the mind, and the relativization ${ }^{18}$ of the mind in order to clear the confusion (the third proposition). ${ }^{19}$ According to this, the relative in the external world is what is described in the definition of the relative; it is to be that whose essence is apprehended with respect to another. ${ }^{20}$ The relative in the mind is isomorphic to the external relative; it is

19 "Relation has (i) one governing rule in existence and (ii) in the mind another governing rule -[this] inasmuch as it is [something] in the mind, not insofar as relativization is concerned." Ibn Sīnā, Metaphysics of Healing, 122. The numbering belongs to me.

20 It is clearly understood from Ibn Sinnā's remarks in al-Ta 'inqāt that the definition of the relative corresponds to the relative in the external world and that this definition does not correspond to the essence itself: "Relation, when apprehended, is a meaning whose essence is apprehended with respect to another - not due to another relation, but due to its essence. (...) In itself, when it is not apprehended, it is not intelligible with respect to another. And [so] substance is, in terms of being a substance, not to be in a subject when in existence. This is the intelligible of the substance, which is one of its concomitants. [Moreover] this intelligible of the substance is an accident in the soul." Ibn Sīnā, al-Ta 'ìqāt, 144. Allan Bäck understood the connection between the definition and the external 
essence apprehended with respect to another. Relativization is the relation layer of the mind's perception of anything (i.e., a property of mental functioning). Ibn Sīnā stated the intelligible of the relative to be unable to lead to an infinite regress in the mind or in the external world, and the reason for this thought is the property of the mind that allows it to perceive the relative. The mind can objectify its own perception and gets caught in an infinite regress when it does. Relativization is real in the first perception and inherent in the intelligible that is isomorphic to the external world; the realization of the relativization, on the other hand, results in invented intelligibles. Interpreting this situation can be attempted as follows: The mind perceives the object compatibly with the conditions of existence in the external world. Because relation attaches to everything that exists, ${ }^{21}$ just as humans perceive objects in terms of remaining as themselves in multiplicity, they also perceive their connection with multiplicity and their positioning according to multiplicity (relativization or relative perception). What is captured in such a perception is the relative essence. However, when the mind objectifies its own act of perception, it can distinguish the property of relation in it. This distinguishing property is what allows the mind to abstract an essence in itself independent of all connections from the object presented to it as embedded in a web of connections. When the mind considers this property of "with respect to," which it distinguished by singularizing it as it does with any intelligible, the situation described in the vertical infinite regress objection occurs: A meaning that is indefinite and completed by performing its linking function requires another indefinite link. However, Ibn Sinnā did not consider this situation to occur during the perception of the relative nor the relative perception/relativization itself to require this. On the contrary, it may occur when the relativization is objectified: "It is possible to have invented

world differently. According to what he wrote in his article, the definition of "the essence that is apprehended with respect to another" from Ibn Sinnā corresponds to the essence in itself, the essence in itself is "relation," and because essence in itself is not qualified as being in the external world or in the mind, the essence of "relation" is neither in the mind nor in the external world. This essence being in the external world means that it is realized in individuals and is a "relative." Allan Bäck, "Avicenna on Relations and the Bradleyan Regress", La Tradition Medievale des Categories (XII ${ }^{e}-X V^{e}$ Siecles), Actes du XIII Symposium Europeen de Logique et de Semantique Medievales, Avignon, 6-10 Juin 2000, eds. J. Biard \& I. Rosier-Catach (Leuven: Edition Peeters, 2003), 69, 74-75. Saying that Bäck's statements here are a kind of interpretation rather than a direct quote of Ibn Sinnās explanations would not be wrong because, in addition to the statements in al-Ta 'i $q$ a $a$, the "special existence" of the relative and its "becoming a species" are mentioned in the passage from Categories quoted above and what follows (Kategoriler [Categories], 155, 157). And the relative at the level of absolute essence, which is not in the mind or in the external world, has come into being and its attachment comes after this.

21 "Every existent (...) has a species of relationship (nisba) and pure relation (idāfa) toward all existents." Ibn Sīnā, Metafizik [Metaphysics], II, 88. 
relations in the mind by reason of the special property the mind has with respect to them." What has been conveyed so far is the part of the solution that addresses the objection based on the vertical infinite regress.

The objection based on the horizontal infinite regress asserts the relative to be a single meaning between two things due to the fact that each relative requires a correlative and is hence in two substrates. Because of this property, an infinite regress occurs between it and its substrates if it exists in the external world. The notion that led to this objection is supported by the fact that there is a determinative signification toward another (i.e., the correlative) in the definition of the relative. To be "that whose essence is defined with respect to another" has been perceived as though it has something other than the relative essence as a constituent element. The relative has even been compared to a road between two cities: The road belongs to whatever city is being considered. ${ }^{23}$

Ibn Sinnā did not discuss the definition of the relative in Metaphysics. However, the following can be gathered from his statements in al-Najāt, Categories, and al-Ta 'ìqāt: Simultaneity is a meaning that is in the essence of the relative. This situation requires only the relative (al-mudāf) and the meaning with respect to which the relation exists (al-mudāf ilayh). Whether al-mudāf ilayh is the object itself or something else is not a situation that the essence necessarily determines.

22 Ibn Sinā, Metaphysics of Healing, 122. The separation of the intellection layers from each other, which is noticed when the intelligible of the relative and the acquisition processes of the intelligible are examined, is important for a consistent understanding of Ibn Sinnă's comments on the relative in various instances. This is because there is another term among those used regarding the relative that makes one think even pure relation is a compound: Relationship (nisba). Ibn Sīnā writes in his explanations that "relation is not pure relationship, on the contrary it is relationship taken repeatedly/mutually." Suhrawardi objected to this description, saying, "If relationship is not an essence suitable to be in the external world, neither is relation because the repetition of something will not turn it into a species." al-Suhrawardi, Kitāb al-Muqāwamāt, ed. Henry Corbin (Paris: Dār Byblion, 2009), 143. However, this statement from Ibn Sinnā implies neither the existence of relationship nor pure relation as repeatedly taken relationship in the external world. The statement at most indicates a state that is more indefinite than the indefinite relation but that creates the possibility for indefinite relation to be apprehended.

23 The example of this in al-Fārābì is "the path between the roof and the floor of the house." al-Fārābī, Kitāb al-Hurūf, trans. Ö. Türker (İstanbul: Türkiye Yazma Eserler Kurumu Başkanlığı Yayınları, 2015), 66. Medieval thinker Albert the Great noted that the approaches of Ibn Sinnā and al-Fārābì to the relative is "conceptualism." The author of the article conveying this information stated that it has not been established on which of Ibn Sīnā and al-Fārābī's texts Albert the Great based this conclusion, but it can be told from Ibn Sinnās statements that he is not only a conceptualist. Brower, "Medieval Theories of Relations"; E. Jeffrey Brower, "Relations Without Polyadic Properties, Albert the Great on the Nature and Ontological Status of Relations", Archiv für Geschichte der Philosophie 83/3 (2001): 234. If the picture of "relative as a meaning that exists between two things" is a conceptualist one, then alFārābỉ's statement in al-Hurüf can be thought to constitute a basis for such a characterization. 
The fact that the relative realized in the external world is simultaneous with its correlative is nothing but the concomitant of the essence in existence. A similar situation is also seen in the definition of the substance. The substance is defined as something that is not in a subject when in the external world. However, not being in a subject is one of the concomitants of the substance. A concomitant was used in the definition of the relative just as in the definition of the substance. That being the case, the definition of the relative as one of the reasons for the vertical infinite regress objection does not correspond to the essence itself according to Ibn Sinnā, and for this reason, it should not be a distraction in the debate about the realness of the relative.

Although Metaphysics does not examine the definition in the context of the solution, Ibn Sinnā clearly stated the notion represented by the road analogy to be wrong: The relative is not a numerically one accident that is subsistent between or associated with two things. The meaning that is relativized to another is separate in each relative from that in the correlative (the fourth proposition) because every object has a separate foundation of relation. The participation of two things as the subjects of the relative accident in one meaning is like the participation of two white objects in whiteness. Each of the white objects has a numerically separate accident of whiteness. ${ }^{24}$ As such, each object has a separate relative accident. Correlatives do not have in common an association with a meaning that is imagined (tawahhum) to run between them as a link, reified separately from them, and numerically one. Of course, there are meanings that correlatives have in common, but this is with respect to singulars having general meanings in common. When two things that contact each other are taken as an example, their participation is in the meanings of contact and association. ${ }^{25}$

The statements in the last lines clearly reveal Ibn Sinnà's insistence that no obstacle occurs to the existence of the relative in the external world. However, these lines also contain something new that will be pointed out from time to time in the second and third sections of this article. This new thing is the presence of an unreified meaning (i.e., an association) between the states that confirm the idea of the participation of correlatives in a meaning. There is also a relational meaning that is not categorical but is among one of the most general predicates of all objects and that Ibn Sinā left out of the framework in which he commented on the

25 Ibn Sīnā, Kategoriler [Categories], 158. 
discussions about relation. What is indicated by association is probably relation, which is this general meaning.

In line with the extensions of the infinite regress objection, Ibn Sinnā proposed a solution to the vertical aspect of the problem by explaining that the relative is a separate species and to the horizontal aspect by explaining that the relative is an accident that occurs in each of the objects, not in between them. At the center of the solution from both sides is the foundation in the object. Relatives becoming a species and each object having a relative accident separately are both explained by the foundation that exists in the external world. In other words, the realness of the foundation and its being numerically one in each object are used to prove the realness and the numerical oneness (wahda) of the relative. Accordingly, the realness criterion and type of the relative is limited to the realness criterion and the type of its foundation. If the foundation is potentially ( $b i-l-f i$ ' $)$ in the object in the external world so is the relative, and if the foundation is actually (bi-l-quwwa) in the object, so is the relative. For example, teachership and studentship are potential in the rational existent with the ability to teach and learn. When this property becomes actualized, the relative is actual. If the object has a mode of existence that is not the subject of motion (e.g., mathematical objects), its relations are also in its mode of existence.

Prominent as the central concept in the analysis of the relative, foundation has previously been mentioned as an essence that is actually classified under the categories of non-relational accidents. Ibn Sīnā's remarks give the impression that a half-independent essence is cut from this essence to be predicated of itself. Indeed, the relative is a separate category but is often characterized as a weak existent. ${ }^{26}$ An essence constituting a foundation in the occurrence of another essence whose individuals exist in the external world is a case that does not convince the conceptualists, and it seems that the existence of the relative, albeit weak, can be rediscussed around the concept of foundation. This is because foundation and pure 
relation are acquired when analyzing a relative. As pure relation is not suitable to exist in the external world, the essence that is accepted as the foundation remains and actually belongs to the category of quantity or quality. Having said that, this article will accept Ibn Sinnā's foundation-centered solution model as is and test its applicability to the meaning of otherness.

\section{The Relative Model and Otherness}

An explanation of the function and definition of the relative requires including the concept of otherness. For this reason, asking the question "What is the minimum and necessary connection of the function and definition of the relative in the external world with otherness?" will be appropriate before examining the existence of otherness in the external world according to Ibn Sīnā's model.

The indirect answer to the question of function that can be found in Ibn Sinnā's texts is that relation is a meaning that preserves the specific oneness of an essence in multiplicity and that is subject to oneness. The essence exists in the external world as many individuals, yet it remains and is perceived as one meaning. The oneness of the essence is its coherence (i.e., remaining as itself in multiplicity). The fact that the coherence is not corrupted in multiplicity is expressed in relative terms that are compatible with the essence in question. ${ }^{27}$ Those that are one in quality are similar, in quantity are equal, in genus are homogeneous, and in species are congenerous. ${ }^{28}$ The multiplicity of those that are one in quality does not mean that the essence, which is the quality, has become multiple or different.

Ibn Sīnā presented an indirect explanation of oneness on the topic of the relative, and an indirect explanation of relation on the topic of oneness. The relative is a category that represents how an essence remains as one in multiplicity. The existence of an essence that is not qualified as being existent or non-existent or as one or many at the level of absolute essence means that it is realized in the external world or, more accurately, makes up the external world by existing. The essence that becomes existent is the subject of the predicate of oneness along with the predicate of existence. As a result, every existent is one. However, the existence of the essence in the external world means that it is realized in singulars (i.e., in multiplicity). In that case, oneness must give the essence an extension that ensures 
both that it is reified as a singular and that it remains as itself in multiplicity. The most general name of the property that ensures this extension is pure relation. The attachment of pure relation to every essence to which oneness is attached brings about a new essence. This new essence is the relative accident that accompanies the singulars of the essence to which oneness is attached. For example, redness is a self-coherent, fixed species but is present in many individuals. Despite their numerical differences, red individuals are one in species when considered in terms of the meaning of redness; they are similar when considered in terms of the numerical difference. Again, in the example of blue pencils of equal length and similar tones, the relatives of equal and similar express their compatibility with multiplicity by remaining as the meanings of length and blueness. Another relative in such an example apart from the ones openly stated, something not mentioned but does exist, is the congenereity (mumäthala) of the pencils. The meaning of pencil is a species that has its own oneness. The state of the multiplicity of individuals in relation to the oneness of the species is expressed through the relation of congenereity: The pencils are congenerous (i.e., like each other). The oneness of every essence that has been realized in the individuals in the external world manifests itself as coherence, and Ibn Sinnā also defended the independence of the category of relative using coherence as a term: "The coherent essences are not real relatives, while the coherence of essences brings about relatives". ${ }^{29}$

When evaluating the connection between definition and otherness with the explanation of the function above, a contradictory situation between definition and function is noticed: The relative is defined as "that whose essence is predicated with respect to another." Whether this definition gives the truth or the concomitant of the relative, the concept of the other in the definition is problematic because, if correlatives are the manifestation of the coherence of an essence (dhāt) in multiplicity, no two things exist other than each other; in the final analysis, what is realized in the individuals is a single essence. The unity of meaning of this essence is not corrupted, and no divergence occurs for itself because of its individuals. At every point where the numerical multiplicity can lead to the imagination of multiplicity and otherness in meaning stands a relative accidental individual that accompanies the realization of the essence in countable ones only as a meaning having oneness, and this is compatible with the nature of the essence. In that case, otherness must be something that the relative excludes, let alone being one of the elements that give the real definition or the description with the concomitant of 
the relative. In other words, the categorical relative is the expression of an existing essence that remains itself and does not diverge in each of the individuals of that essence. If so, then the connection of otherness with the relative can only be at the level of the meaning that must remain outside its definition.

Reversing the problem that arises in the context of the definition of the relative can be attempted by saying that other as a term is used flexibly in place of individual other as a term. Individual other (äkhar) as a term means numerically different, ${ }^{30}$ and Ibn Sinna often used this term in place of other, especially when discussing the definition in terms of correlatives. In view of this, the pencils in the example of the similar blue pencils are not different from each other, they are just the other one to each other. Likewise, the blues present in the pencils are not other than each other, they are the other one to each other. Thus, acknowledging the consistency of Ibn Sinā's explanations becomes possible with a more precise scrutinization of the terms, because by this clarification of terms, real otherness has been excluded from the description and function of the categorical relative. However, this solution of term clarification makes the definition consistent toward the meaning of otherness when applied considering the definition of the relative but does not give the same result when considering the meaning of otherness. In other words, the solution cannot be cross-checked with otherness. Namely, otherness (almughäyara when expressed in the Arabic reciprocal form) is also a relation. What is the ontological status of otherness if the function of the category of relative is the exclusion of otherness in the very essence that is the foundation? Can the existence of the meaning of otherness in the external world be explained somehow, just as the overlap between definition and function can be noticed through term clarification? Or are there meanings that Ibn Sinnā considered exceptions while defending the existence of the relative in the external world? Is otherness one of them? Is otherness also therefore a meaning that does not exist in the external world but is in the mind? If that is not the case, finding a place for a relative that is not dependent on a foundation and exists in the external world will be necessary in Ibn Sinā's analysis of the relative by also taking into account the explanations in his works apart from Metaphysics. This is because every foundation-dependent relative occurs due to the coherence of the foundation, and coherence excludes otherness. There are two possibilities to consider, given these circumstances. The first one is that there are relatives that do not exclude Ibn Sinā's model and exist only in 
the mind, and otherness is one of these. The second possibility is that a relative that is not foundation-dependent exists in the external world. Let us review these possibilities in turn.

Ibn Sinā mentioned some relatives that exist only in the mind but not in the external world. The rule observed in the possibilities of existing in the external world or in the mind is that relatives fulfill the requirement of the condition of equivalence in mode of existence. Relatives can be said to exist in the mind if equivalence cannot be achieved in the external world. The most famous example of this is the relatives of knowledge and the known. The problem that Ibn Sinā also quoted and discussed arises from the fact that the correlatives of knowledge and the known do not provide equivalence in the mode of existence if knowledge about a non-existent occurs. In such a case, knowledge is an existing quality, and the relative that attaches to it is also existent. However, the substrate of the known (i.e., the correlative of knowledge) is non-existent, and consequently the correlative (i.e., the known) is non-existent as well. Ibn Sinnā's opinion is that the extremes are in the external world potentially or equivalent in the mind in such a case because there are two possibilities: Either something that exists in the external world but is not yet known is being indicated, in which case both the known and its knowledge are potential in relation to the external world, or an explanation is being given about the indicated thing, in which case the thing is now distinguished as the object of knowledge and is in the mind simultaneously with this knowledge. ${ }^{31}$ For example, a mechanism whose model has not been made yet is in the mind of the engineer, and the knowledge and the known are in the mind simultaneously. Ibn Sīnā makes the following distinction in this regard: Some things such as knowledge are relative due to their essence; the essence of some things such as similarity/teachership is relative; some things such as redness are relative but not due to their essence. Knowledge is relative due to its essence because it is knowledge of something; however, its essence is in the category of quality. Similarity/teachership has no meaning other than being an essence that is apprehended with respect to something else, so its essence is relative. Redness, on the other hand, does not have to be connected to something like knowledge nor is its essence relative. The condition of equivalence in existence is valid only for those whose essences are relative. There may be differences in the mode of existence of the things that are the relative's substrates. What determines the level at which the 
equivalence happens is the state of its substrate. The relative of a substrate that is in the external world potentially is also potential. For example, if the qualities that will result in being the subject of the teachership predicate are still potential, so is teachership. However, real relatives (i.e., those with relative essences that have occurred), whether they are in the mind or in the external world potentially or actually, are definitely simultaneous.

In the explanation, the state of objects that are the substrates of real relatives becomes prominent as the thing that determines in which mode of existence the correlatives will be simultaneous. If the substrates exist in the external world, so do the relatives. If the substrates are not simultaneous in the external world, their relatives are in the mind. When attempting to apply these explanations to otherness, one can say in advance that the existence of objects qualified by otherness in the external world is necessary, because every existent for which the principle of non-contradiction is valid is something other than another existent. Reducing otherness to being the other one to each other and therefore thinking of a level where no otherness remains means excluding the fundamental distinctions in the structure of reality. If these distinctions are to be preserved, otherness must have a fundamental function in the reality of the external world. Otherwise, a stage can be considered where the otherness between the substances and accidents classified under different categories, most importantly the one between God and the universe, becomes invalid, and accepting that the ultimate reality is an absolute essence will become necessary. ${ }^{32}$ Such a possibility is eliminated in advance due to the principles ${ }^{33}$ that a complete divergence is present between God and the universe and that the categories are neither transitive nor reducible to each other. In this case, the objects qualified by otherness exist in the external world, and there is no obstacle in this respect to the existence of otherness in the external world because the examples said to be present in the mind due to their equivalence being unachievable in the external world are the things that do not exist simultaneously in the external world. However, categories that are other than each other exist simultaneously in the external world. As such, the result of the first possibility in the examination regarding the ontology

32 In fact, Allan Bäck in his article arrived at the conclusion that Ibn Sinnās theory of relation cannot overcome Bradley's infinite regress argument. Bäck, "Avicenna on Relations”, 69-84. Bradley asserted, based on the infinite regress argument, that reality can only be the absolute one, and multiplicity is nothing but appearance. According to this, all relations inhere in the absolute one. The idea of an essence in itself independent from considerations is a crime the intellect commits because of its abstraction ability. Emel Koç, "F. H. Bradley Metafiziği” (PhD diss., Ankara Üniversitesi, 1995), 143, 174. 
of otherness is as follows: Otherness does not meet the requirements of being a relative that exists in the mind and not in the external world.

What is left, then, is to test the second possibility: Relatives signify the coherence of the essence that functions as a foundation and consequently the exclusion of otherness from the essence. Then can otherness be a relative in the external world without being dependent on foundation? Is it possible in general to find categorical relatives that do not have foundations in the external world but that qualify objects in Ibn Sinnā's explanations about the category of relative?

Ibn Sinnàs classification of relatives with respect to whether they have a principle of relation in their substrates or not can be referred to for the answer to this question. As stated in one of the classifications in Metaphysics, (i) sometimes both extremes have a principle of relation, (ii) sometimes only one side has it, and (iii) sometimes neither extreme has a principle of relation. The respective examples of these situations are the lover and the beloved, the knower and the known, the one to the right and the one to the left. Just as a structure exists that is suitable for perception in the lover, so does a structure exist in the beloved that enables them to be perceived by the lover. Knowing is established as a quality in the knower, and the subject becomes a relative to the knower because of this quality. On the other hand, the known becomes relative only because it is the object of knowledge; its essence is not being that which is known, nor is there a quality in it to explain this. As for the example of being to the right and to the left, Ibn Sinnā believed no property to exist in objects that causes them to be to the right and left of each other. The same example had been used before Ibn Sīnā to get different results, and it was stated that, due to fixed directionalities such as the structure of the human body in which organs are positioned in certain places or the uniform motion of celestial bodies, a principle of directional relation exists in some objects, ${ }^{34}$ while other objects are qualified by directional relations through them. Ibn Sīnā cited the example in order to bring the situation where the principle of relation does not exist in either of the extremes closer to the mind. According to this, in the statement "the table to the right of the door," neither the door nor the table has a state that explains being to the right or to the left. ${ }^{35}$ 
The third type in the classification can be considered to exemplify the relatives that exist in the external world without a foundation, and otherness is in this class. However, a more careful look will show that there is a difference between being to the right and otherness. Being to the right is not completely independent of the nature of the essence it qualifies because clearly the objects that are reified as an individual of a species are in positions arranged according to some fixed foci even if they do not require this themselves. This situation makes being to the right and to the left associated again with an essence (i.e., the substance of body), even if indirectly. Meanwhile, the relation of otherness cannot be founded directly or indirectly on a meaning in the composition of any object. The object in the external world can be the subject of the predicates of the right and the left on the condition that it is a body; however, it can be the subject of the predicate of otherness unconditionally. Thus, being to the right has an indirect foundation in the object, and no relative is found in Ibn Sinna's explanations that is not connected directly or indirectly to the nature of the object.

These findings so far have enabled the following answers to be acquired to the question asked regarding the connection between otherness and relation: The relative is a meaning that is subject to the oneness of an essence. A relative that does not have a direct or indirect foundation does not exist in Ibn Sinna's explanation of categories. When evaluating this data alongside the fact that the external world is not an absolute essence, this can be said: Essences must be the subject of otherness in a way that Ibn Sinā's categorical relative model cannot explain. This is because Ibn Sinnā's model requires the relative to be somehow connected to a foundational essence. The failure to provide this connection for itself would require either the negation of otherness in the external world or the acceptance of the infinite regress, and both of these are possibilities that reality rejects. Otherness attaches to every essence without that essence becoming foundational. In other words, it is attached without being specified as a species with the nature of the essence. This situation leads one to trace some concepts and propositions that were excluded from the discussion of the categorical relatives' mode of existence in Ibn Sinnās philosophy and that the philosopher accepted as given but did not make the subject of a special analysis. A consistent interpretation of the concepts and propositions in question will outline the theoretical framework that supports the category of relative and provide the opportunity to evaluate the place of otherness within this framework. 


\section{Pure Relation and Otherness}

Pure relation is prominent among the general concepts that cannot be reduced to any one of the relatives but that explain the conditions for the occurrence of these essences. As will be remembered, Ibn Sinā stated pure relation to exist in the external world not as it is but by becoming a species in the foundation of an essence and that the isomorphic intelligible of this specific essence exists in the mind. The ability of the mind to analyze the process of the occurrence of this intelligible results in objectifying pure relation by distinguishing it, and attributing this distinction to the external world leads to the imagination of infinite regression. These explanations aim to make the what of the relative understandable but do not give information about pure relation itself. An attempt to examine the what of pure relation introduces one to the concept of relationship (nisba), because the clearest description of pure relation is that it is a mutually taken relationship.

One of the first places in the ontology of Ibn Sinā where we encounter relationship, which gives the impression that it is a purer form of pure relation, is the distinction between existence and essence. In Ibn Sinnās threefold consideration of essence, existence attaches to the absolute essence, which is qualified as neither existent nor non-existent, neither one nor many when considered in terms of itself, and makes said essence an existent that is the subject of oneness in the external world. Being an existent in the external world means that the object is in a state where its acts and properties can occur, meaning that it is reified. ${ }^{36}$ However no object is reified in its simple form; on the contrary, it becomes existent equipped with accidents and concomitants. ${ }^{37}$ Acts and properties are only realized through these additions. The additions through which a thing is reified are essences that are separate from that thing and that have other identities. This shows that the reification of the essence occurs in an environment of relationship because an existing object comes into existence with the accidents and concomitants

37 "The truth of an essence, in terms of being that truth, does not exist in a reified state without concomitants. The essence of the first principle is like this as well. It has adjective concomitants. It is one thing in terms of being the truth, and [another] thing in terms of being malzüm (that which must be inseparable from the concomitant), and [still another] thing in terms of being the sum of essences and concomitants (...) Just as we are individualized with additions, it too is reified in terms of being the malzüm of things. In that case, the truth of an essence is a thing in terms of being intelligible in itself without any other condition, and it is another thing in terms of being reified. Thus, an otherness that contains the possibility of relation and relationship (nisba) occurs." Ibn Sīnā, al-Mubāhathāt, ed. M. Bīdārfar (Qom: Intishārāt Bīdār, 1992), 172. 
surrounding it, and its existence continues with these. As a result, it is associated with things that are not itself. However, it is not one of those associated additions, it is itself. For instance, the human substance exists in the external world as a whole of accidents, even its differentia is realized through knowledge, which is a quality; however, it is itself without being reduced to one of its accidents.

Common sense provides the data that otherness is a relational concept, while this examination provides the data that it does not exist in the external world like the objects in the category of relative. Because this examination is about the position of the meaning of otherness in the external world, moving forward should be attempted by investigating the connection between relationship (i.e., the simpler form of pure relation) and the external world.

Ibn Sīnā neither directly analyzed nor made a statement on the connection between relationship and the external world. However, simple and compound predicates themselves (e.g., existence, oneness, identity, and non-contradiction) that qualify everything in the external world are known to have meanings that transcend categories. Therefore, they do not exist in the external world in terms of having individuals that can be pointed at because being an existent in the external world means that the object is in a state of realizing its acts and properties. These general predicates are not objects that are realized themselves but express the conditions in which every object is realized, regardless of its properties and acts. Just as the general predicates do not exist in the external world, the relationship that is inherent in these predicates and ensures the ordering of objects does not exist in the external world either. On the contrary, relationship is the necessary abstract background for the most general states that are predicates to all existents to occur. Relationship is not an existent in the external world. However, if there is an external that is suitable for being noticed by being abstracted through the analysis of the existent, these would be the general predicates, and the best candidate among them may be relationship that pervades all of the general predicates.

When it comes to perception, relationship is not suitable to be an object of perception like any other essence because it is hidden within the principles ordering perception. However, the ability of the mind to objectify its own act allows for analyzing the structure of the act of perception. As a result of such an examination, relationship can be imagined as something that is contentless, separate from the extremes but can be pointed at like them. In fact, in the view that is rejected by being attributed to philosophers in the works of kalam, relationship is designed as an independent individual in the external world. It has been argued that this 
individual, which has no property other than being a contentless link, would need a contentless link similar to itself in order to link the objects; this would lead to an infinite regression, and therefore relationship cannot exist in the external world. However, the connection between relationship and the external world cannot be said to have been established, at least by Ibn Sīnā as presented in the works of kaläm. This is because, not even pure relation as the form of relationship that is considered repeatedly between the extremes exists in the external world unless it is specified in an essence, let alone relationship. In that case, the following can be said for relationship with respect to the reality of the external world: Stating that relationship is an existent in the external world may be correct when referring to the structural property required by the order in which every existent is present. If the existents that have individuals in the external world are being classified under the ten categories, then relationship is not one of these, and for this reason it is a second intelligible in the broad sense.

If this explanation of the connection between relationship and the external world is correct, a conceptual handle has been gained through which the connection between pure relation and the external world can be examined. Namely, relationship requires extremes; in fact, it can only be apprehended after apprehending the extremes. There is nothing more than this in the definition of absolute relationship. Every environment in which the extremes exist requires them to be in a state with respect to each other, and this mutuality is pure relation. Just as the extremes are not included in absolute relationship, the extremes are also not included in pure relation when considering the nature of relationship in the meaning of being in a state with respect to each other. "With respect to" is all that remains. The fact that pure relation is acquired through certain considerations (e.g., being taken mutually) points to its epistemic dimension. However, pure relation in reality is independent of a considering subject, and there is relation in every case where there is relationship. Therefore, the connection of relation with the external world is the connection relationship has with the external world.

The first stage where the concept of pure relation emerges in an analysis of the structure of reality is the meaning of oneness and the principles of identity and non-contradiction that are attached to it. Every existent that is qualified with existence by going from the consideration of "it is neither existent nor non-existent" to the scope of the law of excluded middle becomes the subject of multiplicity at this stage. Existing also means being qualified as being one, and oneness shows its result in the object that is the subject of multiplicity through the principles of 
identity and non-contradiction. Identity establishes the object's self in multiplicity despite multiplicity, while non-contradiction establishes its connection with multiplicity in the way expressed through negation. In this case, oneness is the meaning that ensures both the identity of the existent despite the foreign essences through which it becomes an existent and its simultaneity with these despite its otherness from them. This must be the reason that Ibn Sinna mentioned identity in the group of relative terms subject to oneness and not as absolute oneness in the object. ${ }^{38}$ Indeed, oneness turns into a contradictory meaning if it is not a meaning by which the object is qualified when embedded in such a web of connections. This is because, if oneness does not simultaneously provide the existents A and B with their identity as things that are other than and distinguishable from each other, it can only provide the singularity of an object. In such a case, only one object would exist, and the existence of more than one object in any mode would become problematic. In that case, every existent that is qualified by its identity is also qualified by otherness, and the thing required for this is not only relationship but also pure relation, which expresses the mutuality of the extremes. The meaning that pure relation and consequently otherness are based on is oneness. Oneness can be a predicate to all existents through relation and coextensively with existence. The result of oneness is identity and non-contradiction that accompanies identity. The realness of the identity and non-contradiction principles vouches for the realness of the otherness relation, and the connection of the principles with the external world indicates otherness' level of connection.

Ibn Sinnā's statement that "every existent, especially the existent from whom all existents emanate, has a species of relationship and pure relation toward all existents" is the last stop in which this article will conclude the examination regarding the foundations of otherness in reality. In Ibn Sinnā's explanations about the connection between God and the universe, pure relation appears to be an inherent meaning in the act of the principle of existents that results in otherness. The universe comes into being by emanating (sudūr) from God as a result of His apprehension of His Own Essence. Real otherness, which is the result of the act of apprehending, is described as a state of pure relation that does not have extremes in the Intellect in which a multiplicity does not occur due to its act. In a passage from the chapter of al-Mubahathat discussing the truth of God's self-apprehension, Ibn Sīnā stated the following: 
Three things are understood from the statement "existent by itself." The first is that it has no connection with another thing within the existence of its essence. The second is that the essence does not exist due to anything other than itself, unlike the existence of whiteness for the body. The third is that the essence is relative to itself. Those who think that pure relation requires duality do not see this as possible. On the other hand, those who think that pure relation necessitates only a muḍaff and a mudāf ilayh or even something more general than identity and otherness - and not a mudāf, and a mudāf ilayh other than itself, a second thing, and so on- do not consider it impossible. ${ }^{39}$

We find an explanation supporting these statements in Metaphysics and alNajāt:

Whoever thinks a bit knows that the apprehender necessitates something that is being apprehended. This necessitation does not include the one who is being apprehended to be the same thing or another thing. Similarly, the mover necessitates something that moves. This necessitation itself does not require the one who moves to be the same thing or another thing. On the contrary, another examination necessitates this. That is why it was possible for us to think of a thing that moves by itself until the impossibility of this was proven (...) For this reason, the duality of relatives is known not through relationship (nisba) or relation that is assumed in the mind but through something else. ${ }^{40}$

The fact that nothing other than God is an existent due to itself in all aspects requires the existent to represent (tamaththul) the existence emanating from the principle and the meanings inherent in the existence inside multiplicity. The meaning of pure relation itself does not require another thing; however, the object that cannot exist without multiplicity is the subject of the state of oneness that has pervaded multiplicity and weakened. For this reason, relation will require duality in the object, will be the subject of itself in the divine aspect of oneness, and will be the subject of otherness in the aspect of oneness that pervades the contingent (mumkin) beings.

The specific compounds and individuals of the accidents classified under the category of relation (e.g., pure relation and the concepts subject to it) also being intellectual must be because relation is founded on God's act of intellection. Clearly the emphasis on being intellectual indicates something other than intelligibility because the essences of the body and redness are also intellectual in the sense of being suitable for a mind to apprehend. The emphasis here seems to be on the

40 Ibn Sīnā, al-Najat fí al-manțiq wa-l-ilāhiyyāt, ed. 'Abd al-Raḥmān 'Umayra, II (Beirut: Dār al-Jīl, 1992), 99-100. For similar statements, see Ibn Sīnā, Metafizik [Metaphysics] II, 103. 
coherence of the mind manifesting itself in objects compatibly with their modes of existence. Relation, which does not require extremes in the actual existent in all its aspects or divide the mind, turns into a predicate of which its substrates are unaware in the non-rational objects. The human mind exemplifies both situations: It can understand the aspect of pure relation that does not require multiplicity due to its self-consciousness and understand pure relation as the aspect of oneness that pervades multiplicity due to its ability to apprehend objects while remaining itself.

It has become possible to state that pure relation (and otherness that is subject to it) is a second intelligible in a broad sense, or to use a more precise term, a concept of al-umūr al- 'àmma (common things) due to not being a categorical essence and being among essences' conditions for realization. Thus, otherness is suitable for study as a property of existence.

\section{Conclusion}

Against the view that relatives cannot exist in the external world because of the infinite regress barrier, Ibn Sinnā proposed a solution that highlights the unity of meaning of essence, which is the substrate of the relative. According to this solution, the relative accident is the result of the essence itself, which exists in the external world with many individuals, not being the subject of multiplication and contradiction. All the two things between which there is thought to be a relative accident are actually the substrates of one meaning. Therefore, the idea of two or more things other than each other with one relative accident between them is incorrect, and the reason for the infinite regress objection is this misconception. The correct way is to conceive of the relative as an accident that accompanies every essence realized in the external world by the number of its individuals. The relative accidents in the example of three blue pencils of equal length and similar tones are equality, similarity and congenereity. The meanings of length, blueness, and pencil do not become multiple themselves; the number and state of the individuals in which they exist increase and diversify. The essential unity of meaning in these examples is expressed by the relative accidents in the individuals that compose multiplicity. The things that have a connection of relation between them are not other than each other, they are the other one to each other as individuals of the same categorical essence. In the final analysis, the individual others come to an end in the oneness of an essence. 
According to this solution, the existence of the otherness of two essences completely other than each other in the external world becomes problematic because no unifying third essence exists in relation to which the two will be the other one to each other. Qualifying both as existing is insufficient as a unifying third meaning according to Ibn Sinnā's solution. This is because existence is not a categorical essence. However, otherness is a relation and has a fundamental function in the reality of the external world. The irreducibility of the categories to each other and most importantly the ontological otherness between God and the universe requires an interpretation that explains the realness of otherness as a relative meaning outside the mind. The first thing that can be said in an attempt at such an interpretation is that, when considering Ibn Sīnā's relative model, otherness does not meet the conditions of reification as a categorical accident and therefore has no individual that can be pointed at intellectually.

The following may be noted regarding (i) the connection of otherness with the category, and (ii) its position and function in the external world:

(i) Otherness is not a categorical relative; however, it is one of the principles of the category because, just as identity and non-contradiction are valid for the categories and essences in the universal sense, they are also valid for individuals. The non-contradictory individuals of an essence are qualified by otherness due to non-contradiction. However, this otherness is not real otherness and should turn into numerical otherness. The fusing accidents between numerical otherness as expressed by the term of individual other and the unity of meaning of the essence are categorical relatives.

(ii) The connection of the essence reified in the external world with the accidents and concomitants constitutes a framework that is explained through relationship and relation. Relationship is the simplest meaning required by the simultaneity of the essence and its additions, and the second meaning is pure relation. This is because the essence and its additions are in certain states with respect to each other due to not being the same things and being the extremes of a relationship. The possibility of being in certain states with respect to each other is due to the fact that every relationship is accompanied by a pure relation. Foremost among these specific states is the identity and the non-contradiction of the object. This is because even though every essence is realized through essences other than itself, it is not one of them but is identical to itself. Identity is predicated of the object in an environment of multiplicity composed of things that are each identical to itself and other compared to each other. Otherness is implicitly predicated of 
the object through non-contradiction, which is a predicate in a coequal state to identity. Identity and non-contradiction are the results of oneness, which is one of the most general meanings transcending categories. This is because oneness both gives every object its identity and, similar to existence, is said of all objects that are other than each other as a single predicate as follows: The existent and one are coextensive predicates. If the result of oneness were only identity, this would be a reification restricted to a point and nothing other than one individual would need to exist in the external world. However, the external world is made up of a multiplicity composed of things that are each identical to itself and other than each other. Through relation, which is a meaning that follows oneness and is as general as it, oneness results in the predicates of identity and otherness in objects. Therefore, otherness is the result of relation alongside identity, and relation is the result of oneness. In this case, the question "What is the position of otherness in the reality of the external world?" is equivalent to the question "What is the position of oneness and pure relation?" Whichever group oneness is in among the concepts that explain reality, otherness is also in that group through pure relation.

Stating an existent to be "other" expresses one of the most general predicates, such as saying that it exists and is one, but does not express in which of the ten categories it is. Otherness itself is a meaning that is valid at various levels for every existent including God due to the act of apprehending. For this reason, regarding otherness as a property of existence through oneness would not be incorrect.

\section{Bibliography}

Ammonius, On Aristotle's Categories, Translated by S. Mare Cohen and Gareth B. Matthews, New York: Cornell University Press, 1991.

Bäck, Allan, "Avicenna on Relations and the Bradleyan Regress", La Tradition Medievale des Categories (XIIeXVe Siecles), Actes du XIIIe Symposium Europeen de Logique et de Semantique Medievales, Avignon, 6-10 Juin 2000, Edited by Joël Biard and Irene Rosier-Catach, 69-84, Leuven: Edition Peeters, 2003.

Brower, E. Jeffrey, "Relations Without Polyadic Properties: Albert the Great On the Nature and Ontological Status of Relations", Archiv für Geschichte der Philosophie 83/3 (2001), 225-57.

"Medieval Theories of Relations", Stanford Encyclopedia of Philosophy, https://plato.stanford.edu/ entries/relations-medieval/ (Accessed September 1, 2020).

al-Jurjānī, Sayyid Sharīf, Sharḥ al-Mawāqif: Şerhu'l-Mevâkıf, Translated by Ömer Türker, II, İstanbul: Türkiye Yazma Eserler Kurumu Başkanlığı Yayınları, 2015.

al-Fārābī, Kitāb al-Hurūf: Kitâbu'l-Hurûf, Translated by Ömer Türker, İstanbul: Türkiye Yazma Eserler Kurumu Başkanlığı Yayınları, 2015.

Harari, Orna, "Simplicius on the Reality of Relations and Relational Change", Oxford Studies in Ancient Philosophy 37 (2009), 245-274. 
NAZARIYAT

Henninger, Mark Gerald, Relations: Medieval Theories 1250-1325, Oxford: Clarendon Press, 1989.

Ibn Sīnā, al-Mubāhathāt, Edited by Muḥsin Bīdārfar, Qom: Intishārāt Bīdār, 1423. , al-Najat fi al-manțiq wa-l-ilāhiyyāt, Edited by ‘Abd al-Raḥmān 'Umayra, I-II, Beirut: Dār al-Jìl, 1992. , Kitāb al-Shifã: Kategoriler, Translated by Muhittin Macit, İstanbul: Litera Yayıncılık, 2010. Kitāb al-Shifã: Metafizik, Translated by Ekrem Demirli and Ömer Türker, I-II, İstanbul: Litera Yayınc1lik, 2013.

The Metaphysics of The Healing, Translated by Michael E. Marmura, Provo, Utah: Brigham Young University Press, 2005. , al-Ta 'īqāt, Edited by 'Abd al-Raḥmān Badawī, Beirut: al-Dār al-Islāmiyyah, 1973.

Koç, Emel, “F. H. Bradley Metafiziği”, PhD diss., Ankara Üniversitesi, 1995.

Molac1, Melike, “Güncel Bir İmkan Olarak Stoa Ontolojisi”, PhD diss., Hacettepe Üniversitesi, Sosyal Bilimler Enstitüsü, 2018.

Mullā Ṣadrā, al-Ta līqāt 'alā al-Ilāhiyyāt min al-Shifā' I, Tehran: Intishārāt-i Bunyād-i Ḥikmat-i Islāmīi-i Ṣadrā, 1382.

al-Hikmat al-muta'āliya fi al-asfär al-'aqliyya al-arba'a, Beirut: Dār Ihyāa al-Turāth al- 'Arabī, 1990.

al-Rāzī, Fakhr al-Dīn, Sharḥ 'Uyūn al-ḥikma, Edited by Aḥmad Hịjāzī al-Saqqā, Tehran: Mu’assasat al-Ṣādiq, 1415.

, al-Mabāḥith al-mashriqiyya, Edited by Muhammad Mu tașim Billāh al-Baghdādī, Beirut: Dār al-kitāb al-'Arabī, 1990.

Sorabji, Richard, The Philosophy of the Commentators 200-600, Volume 3: Logic and Metaphysics, London: Bristol Classical Press, 2012.

al-Suhrawardī, Shihāb al-Dīn, Kitāb al-Muqawamāt, Edited by Henry Corbin, Dār Byblion, 2009.

, Kitāb al-Mashāri 'wa-l-muțārahạt, Edited by Henry Corbin, Tehran: Mu'assasa-i Muțālaāàt va Taḥqīqāt-i Farhangí, 1372.

al-Taftāzānī, Sharḥ al-Maqūṣid, Edited by ‘Abd al-Raḥmān ‘Umayra. Beirut, 'Âlam al-Kutub, 1989.

Weinberg, Julius R., Abstraction, Relation and Induction Three Essays in the History of Thought, Madison \& Milwaukee: The University of Wisconsin Press, 1965. 